\title{
AUNC
}

Zabytkoznawstwo i Konserwatorstwo XLIX

Toruń 2018

DOI: http://dx.doi.org/10.12775/AUNC_ZiK.2018.004

\section{Wystrój malarski \\ dawnego luterańskiego kościoła w Rodowie \\ jako postulat duchowej jedności \\ lokalnej społeczności ewangelickiej*}

\author{
PIOTR BIRECKI \\ Zakład Historii Sztuki Średniowiecznej i Nowożytnej \\ Wydział Sztuk Pięknych, UMK w Toruniu \\ piotr.birecki@umk.pl \\ ORCID: 0000-0002-0755-137X
}

Key words: Protestant art, Ducal Prussia, emblems, pietism, Louis XIV, Claude Perrault, Charles le Brun

Słowa kluczowe: sztuka protestancka, Prusy Książęce, emblematyka, pietyzm, Ludwik XIV, Claude Perrault, Charles le Brun

\begin{abstract}
The painting decoration of the former Lutheran church in Rodowo as a postulate of the spiritual unity of the local protestant community

The article presents the hitherto unknown decoration of the furnishing of a little Protestant church in Rodowo (near Prabuty, formerly Rodau/Rohdau) in former Ducal Prussia, founded by the local aristocratic Prussia family of the von Schack. After firstly providing an overview of the complicated confessional history of the region, the church, and its patrons, the second part of this article presents the emblematic decoration of church benches based on the "Four Elements," with models for tapestries designed by Charles Le Brun and published in Paris in 1668 (and later in Germany). The original emblems with descriptions of Charles Perrault refer to King Louis XVI as the ideal ruler, but in Rodowo they emphasize the position of the Prussian nobility as the most important social group in the country. The second part of the article presents four unknown easel paintings on the church walls with a symbolic presentation of Lutheran piety connected with Pietism in Ducal Prussia. The entire artistic ensemble in the church refers to the role of noblemen as leaders in the social and religious life of Ducal Prussia.
\end{abstract}




\begin{abstract}
Abstrakt
Artykuł prezentuje mało znaną dekorację malarską wyposażenia małego, protestanckiego kościoła w Rodowie koło Prabut fundowanego przez arystokratyczną pruską rodzinę von Schacków w dawnych Prusach Książęcych. W pierwszej części zaprezentowane zostały skromnie reprezentowane w źródłach i literaturze dzieje wsi, kościoła i samej rodziny. W drugiej części omówiono dekorację emblematyczną wykonaną na licach ław, opartą o „Cztery Elementy”, zespół projektów zaprojektowanych przez Charlesa le Brun i opublikowanych w Paryżu w 1668 roku (później w Niemczech). Francuskie oryginały, z opisami Charlesa Perrault nawiązywały do króla Ludwika XIV jako idealnego władcy, ale w Rodowie odniosły się do roli pruskiej szlachty jako najważniejszej grupy społecznej w Prusach Książęcych. Trzecia część artykułu omawia cztery owalne obrazy sztalugowe nawiązujące swą tematyką do luterańskiej pobożności związanej z pietyzmem oraz prezentującej szlachtę jako swoisty zwornik stabilnej struktury społecznej i religijnej w Prusach Książęcych.
\end{abstract}

W Rodowie, niewielkiej miejscowości w pobliżu Prabut, stoi niewielki kościół z XVIII wieku, którego prosta forma architektoniczna nie zdradza mijającym go bogatego i ciekawego pod względem ikonograficznym wystroju malarskiego. Wystrój ów tworzy zespół emblematycznych dekoracji umieszczonych na licach ław oraz cztery duże, owalne malowidła sztalugowe zawieszone na jego ścianach. Wymowa dekoracji jest wyraźnie czytelna: gloryfikują właścicieli wsi jako ziemskich opiekunów mieszkańców ich majątku oraz wskazują na wartość życia duchowego, którego rozwój zapewnia posługa tutejszych pastorów. Harmonijna koegzystencja tych, którzy bronią, i tych, którzy się modlą, oraz tych, którzy pracują, miała zapewnić stabilność lokalnej, a nawet szerzej - ponadlokalnej społeczności ewangelickiej w Prusach Książęcych. Rodowskie emblemy, oparte na projektach emblemów z tapiserii dla Ludwika XIV, oraz malowidła przypominające o sile indywidualnej modlitwy, inspirowane duchowością pietystyczną, stanowią wyjątkowy w dawnych Prusach przykład zobrazowania przedstawienia postulowanej przez Marcina Lutra tradycyjnej struktury społecznej.

\title{
Zmiany wyznaniowe w Prusach Książęcych
}

W wyniku postanowień drugiego pokoju toruńskiego dawne Państwo Zakonne zostało podzielone na Prusy Królewskie (część południowo-zachodnia) oraz Prusy Krzyżackie (część północno-wschodnia). W 1525 roku ostatni wielki mistrz krzyżacki Albrecht Hohenzollern (von Brandenburchg-Ansbach) 
przyjął książęcy tytuł dux in Prussiae, zsekularyzował swoje władztwo, odtąd zwane Prusami Książęcymi, i wprowadził wyznanie reformacyjne, w Niemczech pozostające jeszcze w fazie wczesnokonfesjonalizacyjnej. Tym samym książę Albrecht utworzył pierwsze luterańskie państwo w Europie. Wprawdzie oficjalnie nowe wyznanie w Prusach Krzyżackich/Książęcych wprowadzono w 1525 roku, lecz działania w tym kierunku były podejmowane znacznie wcześniej. Już w 1523 roku wysłani przez Marcina Lutra do księcia dwaj duchowni wygłosili w kościołach Królewca - Johannes Briesmann (uczeń Lutra, późniejszy kaznodzieja katedry w Królewcu) ${ }^{1} 27$ września, a dawny kaznodzieja odpustowy z Holsztyna Johannes Amandus (Amandi) ${ }^{1} 29$ grudnia - pierwsze kazania w duchu luterańskim; gromadzić miały one tłumy. Z kolejnymi kazaniami wystąpili biskupi Georg von Polenz² z Sambii i Erhard von Queis ${ }^{3}$ z Pomezanii. Pierwszy z nich, dawny członek zakonu krzyżackiego i przyjaciel Albrechta Hohenzollerna z czasów wspólnej służby u cesarza Maksymiliana I, pełnił funkcję regenta podczas nieobecności księcia w Prusach w latach 1522-1525. Drugi - von Queis, duchowny Zakonu, autor reformacyjnego dzieła „Themata episcopi Riesenburgensis“, już w 1523 roku był gorącym zwolennikiem reformy Kościoła, zarządzając sekularyzację dóbr kościelnych, w tym majętności w Prabutach, gdzie na tamtejszym zamku mieściła się jego rezydencja. Temperaturę zmian w pejzażu wyznaniowym podgrzewały spory ikonoklastyczne, ale te szybko wygaszono ${ }^{4}$. Działania pro-

1 Adolf Brecher, „Amandus, Johannes“, w Allgemeine Deutsche Biographie, t. 1, (Leipzig: Stadt Verlag, 1875), 389.

2 Karl A. von Hase, „Polenz, Georg von“, w Allgemeine Deutsche Biographie, t. 26, (Leipzig: Stadt Verlag, 1888), 382-385.

3 Paul Tschakert, Urkundenbuch zur Reformationsgeschichte des Herzogtum Preussen (Leipzig: Breitkopf und Härtel, 1890), 39.

4 Sergiusz Michalski, „Bilderstürme im Ostseeraum“, w Macht und Ohnmacht der Bilder. Reformatorischer Bildersturm im Kontext der europäischen Geschichte, red. Peter Blickle, André Holstein, Heinrich Richard Schmidt, Franz Josef Sladeczek (München: Oldenbourg Wissenschaftsverlag 2002), 228; Sergiusz Michalski, „'Hölzer wurden zu Menschen'. Die reformatorischen Bilderstürme in den baltischen Landen zwischen 1524 und 1526“, w Die baltischen Lande im Zeitalter der Reformation und Konfessionalisierung. Livland, Estland, Ösel, Ingermanland, Kurland und Lettgallen. Stadt, Land und Konfessionn 1500-1721, red. Matthias Asche, Werner Buchholz, Anton Schindling, Teil. 4 (Münster: Achendorf Verlag 2012), 148; Janusz Małłek, „Początki protestantyzmu w Prusach Książęcych“, w Opera selecta, t. 4 (Toruń: Wydawnictwo Naukowe UMK, 2012), 233-249. Na temat pobożności mieszczan przed reformacją zob. m.in. Alltag und Frömmigkeit am Vorabend der Reformation in Mitteldeutschland. Katalog wystawy „Umsonst ist der Tod” (Leipzig: Universität Verlag, 2013) oraz Janusz Małłek, „Ludność staropruska a Reformacja”, Gdański Rocznik Ewangelicki vol. XI, t. 5 (2011): 41-56. 
reformacyjnie zorientowanego władcy doprowadziły do tego, że w 1528 roku dwieście dziewiętnaście parafii przekształcono w parafie ewangelickie ${ }^{5}$.

W stołecznym Królewcu powstała Albertina - jeden z najsilniejszych uniwersytetów pobrzeża Bałtyku, który miał przygotowywać kadrę duchownych dla parafii ewangelickich. Albertina przyciągała także kandydatów na pastorów z Prus Królewskich oraz z Wielkiego Księstwa Litewskiego, które w stołecznym Wilnie i dobrach radziwiłłowskich najpierw absorbować zaczęło wpływy luteranizmu, a potem kalwinizmu ${ }^{6}$. Dzięki tamtejszym drukarniom Królewiec stał się też centrum wydawniczym literatury ewangelickiej, w tym traktatów i polemik. Pierwszą drukarnię założył w tym mieście gdańszczanin Johannes Weinreich, prowadził ją w latach 1523-1553 i wydał 103 druki, w tym „Wyznanie wiary chrześcijańskiej” Jana Seklucjana z 1544 roku. Jako drugi powstał działający w latach 1549-1556 zakład Aleksandra Augezdeckiego, w którym wydrukowano m.in. pierwszy polski przekład Nowego Testamentu w tłumaczeniu Stanisława Murzynowskiego oraz Postyllę polskq domowa (1556) pióra Grzegorza Orszaka. W trzeciej oficynie drukarskiej - Jana Daubmanna - w latach 1554-1575 wytłoczono około 240 tytułów, w tym w 1558 roku dzieło Erazma z Rotterdamu Rycerstwo chrześcijańskie a żywot duchowy, a gdy kierował nią zięć Daubmanna Georg Osteberger wydano kolejne druki łacińsko-, niemiecko- i polskojęzyczne. Szacuje się, że tylko w XVI wieku w Królewcu łącznie ukazało się ponad sześćset tytułów. Książki, liczne traktaty i druki specjalne tłoczono równie dynamicznie w następnym okresie: w wiekach XVII, kiedy to działała drukarnia Reussnerów, oraz XVIII, gdy pracowały oficyny Jana Henryka Hartunga, Gabriela Droyera i Johanna Friedricha Driesta ${ }^{7}$. Dzięki rozwiniętej produkcji drukarskiej oraz

5 Franz Dittrich, „Geschichte des Katholizismus in Altpreussen von 1525 bis zum Ausgange des achtzehnten Jahrhunderts“, Zeitschrift für Geschichte und Altertumskunde Ermlands, 13 (1901): 28.

6 Piotr Birecki, "Reformed Church Buildings in the Grand Duchy of Lithuania in the Modern Period", Reformation and Renaissance Review 17, nr 1 (April), red. Piotr Wilczek, Simon Burton, (2015): 17-30.

7 Literatura na temat drukarstwa w Królewcu jest bardzo bogata, zob. m.in. Władysław Chojnacki, „Z dziejów drukarstwa polskiego w Królewcu”, Komunikaty Warmińsko-Mazurskie 1 (1961): 21-38; Paul Schrenke, „Hans Weinreich und die Anfänge des Buchdruckerei in Königsberg”, Altpreusische Monatschschrift (Neue Folge) 33 (1896): 67-109; Karl Lohmeyer, Geschichte des Buchdrucks und des Buchhandels im Herzogthum Preussen (16. und 17. Jahrhundert), (Leipzig: Stadt Verlag, 1896); Ingrid Arp, „Hans Daubmann und der Königsberger Buchdruck im 16. Jahrhundert. Eine Profilskizze“, w Königsberger Buch und Bibliotheksgeschichte, red. Axel E. Walter (Verlag Köln Weimar Wien, Böhlau, 2004), 88-125. 
licznym importom książek i grafik sztuka w Prusach Książęcych przez całą epokę nowożytną mogła korzystać z europejskich wzorów ikonograficznych i kompozycyjnych.

Wydanie Biblii w tłumaczeniu Lutra, przełożonej także na język staropruski, było jednym z silniejszych impulsów chrystianizacyjnych w dawnych Prusach Krzyżackich. Książę Albrecht polecił biskupowi von Polenzowi, by w ramach wizytacji parafii katolickich wprowadzono w nich reformy organizacyjne oraz zgodne z reformą luterańską zmiany w liturgii. Jego wysiłki wcielali w czyn: wizytator kościelny i komisarz książęcy Adrian von Waiblingen ${ }^{8}$, kształcony we Freiburgu Bryzgowijskim, w Paryżu i w Wiedniu, późniejszy kaznodzieja dworski Paulus Speratus ${ }^{9}$, Martin Meurer, kaznodzieja z Kętrzyna i późniejszy pastor przy królewieckim kościele w Löbenicht ${ }^{10}$. Działania tych duchownych przyspieszyły ewolucyjny w swej naturze proces przekształcania się parafii katolickich w ewangelickie i budowy sieci parafii, które utworzyły lokalny, pruski Kościół luterański ${ }^{11}$. W 1530 roku ukazały się „Statuta synodalia”, kompendium wytycznych regulujących funkcjonowanie wyznania luterańskiego w Prusach Książęcych oparte na Confessio Augustana ${ }^{12}$.

Silny związek Księstwa i Kościoła - i w konsekwencji stabilna sytuacja tutejszych ewangelików - sprawił, że państwo Albrechta i jego następców omijały zarówno konflikty wyznaniowe, jak i działania kontrreformacyjne. Dzięki temu średniowieczne kościoły pokatolickie, najczęściej z nowym wyposażeniem, służyły przez setki lat jako siedziby parafii luterańskich. Można też było w Prusach Książęcych budować nowe kościoły oraz kaplice, i to dla luteranów, jak i dla kalwinistów. Na przykład Jean de Bodt wzniósł w Kamieńcu Suskim w 1756 roku dla von Finckensteinów okazałą budowlę wzorowaną na słynnym kalwińskim kościele we francuskim Charenton, a Joachim L. Schultheiß von Unfried zbudował w Łabędniku w 1730 roku kaplicę grobową dla von Groebenów) ${ }^{13}$. Dawne katolickie wyposażenie początkowo adaptowa-

8 Erich Joachim, Walter Hubatsch, Regesta Historico-Diplomatica Ordinis S. Mariae Theutonicorum 1198-1525 (Göttingen: Vandenhoeck \& Ruprecht Verlag 1973), 343; Tschakert, Urkundenbuch, 154.

9 Paul Tschakert, „Speratus, Paulus“, w Allgemeine Deutsche Biographie, t. 35, (Leipzig: Duncker \& Humboldt, 1893), 123-135.

10 Tschakert, Urkundenbuch, 385.

11 Małłek, „Początki protestantyzmu“, 244-246.

12 Małłek, „Początki protestantyzmu“, 233.

13 Jan Harasimowicz, „Der Kirchenbau im konfessionellen Zeitalter“, Das Münster, 69, nr 1, (2016): 7-8. 
no do nowych celów służących dydaktyce teologicznej np. dodając inskrypcje z biblijnymi cytatami do malowanych tablic na ołtarzach, z których nie usuwano zazwyczaj „niebiblijnych postaci”. Nie obawiano się pozostawiać gotyckich szaf ołtarzowych bez ingerencji w ich materialną strukturę, czego dowodem jest m.in. gotycki ołtarz w Rychnowie koło Olsztynka ${ }^{14}$. Wyposażanie kościołów, całkowicie na nowo, głównie w XVII wieku, stało potrzebą świeckich fundatorów - kolatorów, którzy zaczęli je przekształcać w „prywatne" kościoły rodowe ${ }^{15}$.

Spora grupa średniowiecznych kościołów w Prusach Książęcych otrzymała w wieku XVII nowe ołtarze, kazalnice, chrzcielnice, ławki, empory i instrumenty organowe. Nie fundowano w nich figuralnych polichromii ściennych, za to płyciny empor zyskiwały malarskie sceny będące prezentacją całego spektrum tematów biblijnych - przykładem są kościoły w Dąbrównie, Prabutach, Malborku, Kętrzynie, Przezmarku. Większość wątków opowiadających o dziejach Zbawienia pochodziła ze Starego i Nowego Testamentu. W XVII stuleciu zaczęły pojawiać się - np. w Starym Mieście pod Dzierzgoniem i w Pasłęku - również tematy czerpiące z duchowości pietystycznej, oparte ikonograficznie na takich dziełach, jak Pia Desideria Philippa Jacoba Spenera, Amoris divini emblemata Otto van Veniusa, albo na „serdecznych” emblematach Daniela Cramera, obecnych m.in. w dekoracjach kościołów w sąsiedztwie Królewca, a w Prusach Królewskich - w zdobieniach ław prezbiterialnych kościoła w Pruszczu Gdańskim ${ }^{16}$.

14 Piotr Birecki, „Architektura i sztuka na terenie Prus Książęcych (1525-1657), Prus Brandenburskich (1657-1701) i Prus Wschodnich Królestwa Pruskiego (1701-1817)”, w W 500-lecie reformacji (1517-2017). Z dziejów Kościołów ewangelickich $w$ dawnych Prusach Królewskich i Książęcych, t. 2 Tereny dawnych Prus Książęcych, red. Jarosław Kłaczkow, Grzegorz Jasiński, Piotr Birecki (Toruń: Wydawnictwo Adam Marszałek, 2017), 83, 97.

15 Podobny proces następował m.in. w kościołach wschodniego pobrzeża Bałtyku, zob. Krista Kodres, „Das Kirchengebäude: Privatprojekt des Gutbesitzers? Das Beispiel Estlands in der Frühen Neuzeit“, w Protestantischer Kirchenbau der Frühen Neuzeit in Europa, red. Jan Harasimowicz (Regensburg: Schnell \& Steiner 2015), 271-282; Piotr Birecki, „The Lutheran Church as a Space of Representation of Social Standing in Early Modern Ducal Prussia“ (referat na sesji Indifferent Things? The Material and Ceremonial Church Practices in the 16th and 17th Centuries in the Baltic Sea Region. The conference in the series of „Homburger Gespräche" and the 5th conference in honour of Prof. Sten Karling (1906-1987), [Tallin 14.09.-16.09.2017] - artykuł w druku.

16 Birecki, „Architektura i sztuka”, 127-132. Chrzanowski, Tadeusz. 1994, „Kościół w Starym mieście pod Dzierzgoniem pw. św. Apostołów Piotra i Pawła - emblematyka w służbie protestantyzmu". In Sztuka Prus XIII-XVIII wieku, edited by Michał Woźniak, 199-226. Toruń: University Press. 
Ważnym polem aktywności fundatorów były, prócz wystroju i wyposażenia kościołów, funeralia: płyty nagrobne, epitafia, spolia, pomniki nagrobne (np. Frédérica von den Groeben w Łabędniku) oraz witraże heraldyczne i metalowe lub tekstylne chorągwie pogrzebowe (np. chorągwie Botha von Eulenburg i Wilhelma Schack von Wittenau). Jako główny temat epitafiów obrazowych najczęściej wybierano Chrzest w Jordanie, Ukrzyżowanie, Zmartwychwstanie, Sąd Ostateczny; jego uzupełnieniem były portrety zmarłych fundatorów, modlących się samotnie lub wraz z rodzinami np. pod krzyżem Chrystusa ${ }^{17}$. Przykład trwającej setki lat opieki fundatorów nad kościołem leżącym w obrębie ich majątków znajdujemy w Rodowie.

\section{Z dziejów Rodowa}

Nowożytny luterański kościół w Rodowie oraz jego wyposażenie i program ikonograficzny dekoracji malarskich nie były dotąd przedmiotem szerszych badań. W niniejszych rozważaniach - zwracając uwagę na wyjątkowość tego obiektu przedstawiam krótko dzieje wsi i kościoła, omawiam jego wystrój i podejmuję próbę analizy treściowej zespołu malarskiego, podkreślając, że rodowskie dekoracje te są przykładem wyjścia poza tradycyjną dydaktyczną funkcję malarstwa luterańskiego w Prusach Książęcych.

Historycy nie dysponują wystarczającymi źródłami do rekonstrukcji średniowiecznych i nowożytnych dziejów Rodowa - podobnie jak wielu wsi w tej części Prus. Wieś Rodowo („Gross Rohdau” lub „Rodau”) była częścią dóbr należących do Prabut. Pierwszą o niej wzmiankę odnotowano około 1285 roku: Rodowo („Radowe”) wymieniono wtedy jako należące do rycerza Dietricha Stange i jego potomnych ${ }^{18}$. Kolejne informacje pochodzą z 1323 roku gdy wyznaczano granice z sąsiednimi dobrami Gonty, oraz z 1323 i 1361 roku kiedy biskup Mikołaj nadał sołtysowi Segehardowi nowy przywilej osadniczy, a mieszkańcom „Rodow” przywilej lokacyjny i 70,5 łana ziemi. W zapiskach potwierdzających zawarcie transakcji gruntowych kilkakrotnie wspomniano o miejscowym proboszczu (np. Mikołaju w roku 1336), a także o uposażeniu świątyni w cztery łany ziemi $(1361)^{19}$. Nieznany nam bliżej średniowieczny

17 Birecki, „Architektura i sztuka”, 127.

18 Max Perlbach, „Zur Geschichte des ältesten Großgrundbesitzes im Deutschordenslande Preussen: Dietrich von Dypenow und Dietrich Stange“, Altpreussische Monatsschrift 39 (1902): $78-124$.

19 Karl J. Kaufmann, Geschichte der Stadt Rosenberg in Westpreussen (Rosenberg: Stadt Verlag 1937), 178. 
kościół w Rodowie wymieniono w 1336 i w 1361 roku jedynie przy okazji transakcji majątkowych i w rejestrach zniszczeń regionu podczas wojen polsko-krzyżackich w latach 1409-1411 i 1454-1466 ${ }^{20}$.

Nowożytne wzmianki o wsi Rodowo są równie lakoniczne. Przykładem jest zapiska z 13 lutego 1561 roku w dokumencie, w którym książę Albrecht nadał niejakiemu Jacobowi Rosteckowi ziemię w Rodowie na prawie chełmińskim. Uzyskany przywilej dotyczył także następnego właściciela Rodowa Wenzela Schack von Stangenberg (ze Stążek) i jego potomków. Ta pruska rodzina pisała się też jako Schack von Wittenau (z Witenowa) - zgromadziła okoliczne dobra i przyczyniła się do ich gospodarczego rozwoju. W kolejnym stuleciu znaczenie polityczne rodziny Schack von Wittenau, powiększającej sukcesywnie swój majątek, ciągle rosło. W 1700 roku biskup chełmiński Teodor Potocki, który ignorował obecność luteranizmu w swojej diecezji i rościł sobie prawo do duchowego przywództwa nad wszystkimi wiernymi w jej granicach, zanotował w aktach wizytacyjnych, że w 1691 roku Margareth Schack von Wittenau (1636-1702) pod zwierzchnictwo „synagogi luterańskiej w Rodowie w Prusach Książęcych” włączyła wsie Balewo, Linki, Cieszymowo, Stążki, Perklice i Dworek. Zapis ten może wskazywać na niepoślednią rolę parafii w Rodowie w obrębie dóbr należących do rodziny Schack von Wittenau, chociaż miejsce pochówków dla swego rodu Schackowie urządzili w parafii w nieodległym Suszu ${ }^{21}$.

Członkowie rodziny Schack von Wittenau pełnili różne funkcje w administracji i armii książęcej, dzięki temu w XVII i XVIII stuleciu ciągle cieszyli się w Prusach i poza krajem dużymi wpływami politycznymi i ekonomicznymi. Fundator wyposażenia kościoła w Rodowie, Wilhelm Albrecht Schack van Wittenau, służył jako generał major w armii Fryderyka IV, króla Danii i Norwegii, brał po jego stronie udział w wojnie przeciw Szwedom i Holsztynowi, prawdopodobnie między 1700 a 1720 rokiem walczył pod Lille, Stralsundem, Bonn i Namur. Uczestniczył też w wojnach po stronie Ludwika XIV z tzw. koalicją augsburską, o sukcesję hiszpańską i w trzeciej wojnie północnej toczącej się w latach 1700-1721 pomiędzy Królestwem Danii i Norwegii, Saksonią, Rosją, Prusami i Hanowerem przeciw Szwecji ${ }^{22}$. Jego dokonania wojenne

\footnotetext{
20 Kaufmann, Geschichte der Stadt Rosenberg, 178.

21 Archiwum Diecezjalne w Pelpinie, sygn. 33, Wizytacja biskupa Teodora Potockiego, karta nn.

22 Łukasz Szczepański, „Życie i kariera wojskowa generała majora Wilhelma Albrechta Schack von Wittenau", w Suski słownik biograficzny, 58-60, http://docplayer.pl/43206697-Zycie-i-kariera-wojskowa-generala-majora-wilhelma-albrechta-schack-von-wittenau.html (do-
} 
upamiętnia inskrypcja na metalowej chorągwi nagrobnej (zmarł 22 maja 1731 roku) ozdobionej stosownymi panopliami i zawieszonej w kościele w Suszu ${ }^{23}$. Wilhelm Albrecht Schack van Wittenau poślubił hrabinę Henriette Sibylle Truchsess von Waldburg, która urodziła mu pięciu synów; otrzymali oni imiona: Magnus Ludwik, Wilhelm Henryk, Jan Grzegorz, Fryderyk Benjamin i Karol Albrecht. Najmłodszy, Karol Albrecht, jako oficer (w stopniu majora, pułkownika, później generała majora) służył królom polskiemu i pruskiemu. Podpisał konfederację dysydentów w Toruniu, a następnie wybrano go na jej delegata na sejm delegacyjny 1767/1768 roku; 14 maja 1777 roku otrzymał Order św. Stanisława, ustanowiony przez polskiego króla Stanisława Augusta Poniatowskiego ${ }^{24}$. Karol Albrecht był też fundatorem w połowie XVIII wieku nowego kościoła w Rodowie oraz części jego wyposażenia meblarskiego i naczyń liturgicznych ${ }^{25}$.

\section{Kościół w Rodowie}

Funkcję kolatora świątyni katolickiej, a potem luterańskiej w Rodowie pełnili właściciele tutejszych dóbr ziemskich. Pierwszy drewniany kościół, którym się opiekowali, jak się przypuszcza, uległ zniszczeniu podczas wojny polsko-krzyżackiej zwanej głodową, ale wkrótce został przez nich odbudowany. Nie ma niestety jakichkolwiek bliższych wiadomości o tym obiekcie

stęp 10. 05.2018) - w tekście bibliografia; Aleksander Klemp, Protestanci w dobrach prywatnych w Prusach Królewskich od drugiej połowy XVII do drugiej połowy XVIII wieku (Gdańsk: Ossolineum, 1994), 90.

${ }^{23}$ Reprodukcję wizerunku Wilhelma Albrechta Schack zu Wittenau na chorągwi pogrzebowej, zob. Irma Kozina, Jan K. Ostrowski, „Grabfahnen mit Porträtdarstellungen in Polen und in Ostpreußen”, Zeitschrift für Kunstgeschichte 55, nr 2 (1992): 242.

24 Szczepański, „Życie i kariera”, 62; Mariusz Machynia, Czesław Srzednicki, Oficerowie dawnej Rzeczypospolitej 1777-1794, t. 1 Oficerowie wojska koronnego, cz. 3 Piechota (Kraków: Wydawnictwo Naukowe, 1998), 85-107; Wojciech Kriegseisen, Ewangelicy polscy i litewscy w epoce saskiej 1696-1763 (Warszawa: Wydawnictwo Naukowe Semper, 1996), 264; Łukasz Szczepański, „Chorągiew nagrobna Wilhelma Albrechta Schack von Wittenau z Sanktuarium św. Antoniego w Suszu”, Skarbiec Suski 8 (2013): 14-25.

25 Jerzy Dygdała, „Schack von Wittenau Karol Albert (1711-1782?)”, w Polski słownik biograficzny, t. 35, red. Henryk Markiewicz (Wrocław 1994), 390; Iława. Z dziejów miasta i powiatu, (Olsztyn: Wydawnictwo Pojezierze 1972), 76; Die Bau- und Kunstdenkmäler der Provinz Westpreussen, z. 12, Schmid Bernard, Kreis Rosenberg (Danzig: Komissions Verlag 1906), 89. Naczynia liturgiczne: hostierka (Oblatendose) z napisem „Carl Albrecht Schack von Wittenau Henriette Elisabeth von Golz 1750” i srebrny kielich z taką samą inskrypcją nie zachowały się. Niedawno odkryto kilka metalowych tarcz herbowych, które zdobiły trumny von Schacków (w tym imienne: Anny Elizabeth oraz Carla Albrechta Schack von Wittenau). 
i jego wyposażeniu. Następna wzmianka kościoła, pochodząca dopiero z 1543 roku, informuje o jej ponownym całkowitym zniszczeniu. Ponieważ w epoce wczesnonowożytnej zapiski o kościele w Rodowie pojawiały się sporadycznie, można założyć, że w historii tutejszej parafii zdarzały się okresy, kiedy stan obiektu uniemożliwiał jego użytkowanie, lecz nie podejmowano odbudowy. Świadczyć o tym może kolejna, równie lakoniczna wzmianka o drewnianym budynku kościelnym pochodząca dopiero z 1624 roku, zamieszczona w księdze rachunkowej miasta Prabuty z lat 1689-169026. Świątyni tej nie było już w 1754 roku, kiedy wzniesiono murowany bezwieżowy obiekt, być może dokładnie na miejscu poprzedniej budowli (można tylko przypuszczać, że ich obrysy się pokryły). Z jego wyposażenia zachowały się trzy polichromowane płyciny przedstawiające cnoty Benignitas (Dobroć), Castitas (Czystość) i Patientia (Cierpliwość), które dekorowały policzki ławek pochodzących prawdopodobnie jeszcze z XVII wieku. Obecnie Patientia pozostała na licu ławki ustawionej na emporze zachodniej, a Benignitas i Castitas połączono i wstawiono w płycinę ławy w prezbiterium. Obrazy te powstały najprawdopodobniej według grafik Crispijna van de Passe i datować je można na pierwszą połowę XVII wieku, czyli na okres budowy świątyni wzmiankowanej w 1624 roku.

Budowę nowego kościoła w 1754 roku upamiętniła płyta inskrypcyjna wmurowana nad południowym wejściem. Budowniczy realizował inwestycję na podstawie planów nieznanego architekta, który wzorował się na kościele w sąsiednim Gdakowie. Tamtejszy kościół powstał w latach 1753-1755 dzięki wysiłkowi Bogumiła (Gottlieba) Haselbechera, polskiego architekta mieszkającego w Gdakowie, który z kolei wykorzystał plany sporządzone przez pruskiego królewskiego mistrza budowlanego Garlinega [Garlinga?] ${ }^{27}$. Czy zatem Haselbecher mógł być architektem bądź wykonawcą obiektu w Rodowie?

Część zachowanego do dziś wyposażenia rodowskiego kościoła jest starsza i pochodzi z wcześniejszej budowli. Kazalnica, o wyjątkowej w Prusach Książęcych dekoracji figuralnej, datowana na 1690 rok, powstała w warsztacie rzeźbiarza Johannesa Soeffrensa młodszego (a nie - jak wcześniej przy-

26 Kaufmann, Geschichte der Stadt Rosenberg, 178.

27 Mistrz budowlany Galring (Garlieng) nadzorował budowę podobnego w formie kościoła w Kurkach, wykonawcą tej inwestycji był w latach 1751-1752 Johann Friedrich Döhnert, zob. Geheimes Staatsarchiv Berlin-Dahlem, XX, EM, sygn. 100d, Nr 68, Die Kirchenbau zu Kurcken betreff., k. 27-117. Niestety, mimo przeprowadzonej kwerendy w archiwach polskich i niemieckich (w tym w Evangelisches Zentralarchiv w Berlinie), podstawa źródłowa niniejszego tekstu nie jest zadowalająca. 
puszczano - w warsztacie Joachima Sebastiana Doebla). Jego ręce przypisać można też figurę wiszącego niegdyś przed ołtarzem anioła chrzcielnego ${ }^{28}$.

Na zachodniej emporze kościoła zachował się wyryty na parapecie podpis Johann Heinrich Selcke - sygnatura mistrza pracującego przy jej wyposażeniu i który w 1741 roku zbudował ołtarz w kościele w Iławie ${ }^{29}$. To pozwala przypuszczać, że ołtarz, chrzcielnica, figura zmartwychwstającego Chrystusa oraz organy zwieńczone figurami Mojżesza, archanioła Michała i Jana Chrzciciela znalazły się w Rodowie w nowym kościele wzniesionym w 1754 roku i pochodzą z warsztatu Selckego ${ }^{30}$. Cztery duże owalne malowidła powstały (o czym mowa poniżej) na podstawie dzieł graficznych opublikowanych w 1670, 1687 lub w 1690 roku, co może wskazywać, że namalowano je w trzeciej ćwierci XVII wieku i przeniesiono ze starego do nowego kościoła, nie do końca dobrze wpisując się w jej podziały wewnętrzne ${ }^{31}$.

\section{Wystrój malarski kościoła w Rodowie}

Przystępując do prezentacji i wstępnej analizy wystroju malarskiego wnętrza kościoła w Rodowie należy uprzedzić, że nie zachowało się ono w oryginalnym stanie. Wszystkie herby rodzinne von Schacków oraz niewielka część malowideł emblematycznych umieszczonych na przednich ściankach ławek zaginęła, udało się jedynie odnaleźć w kościele w Pasłęku jedną płycinę z emblemem pochodzącym w Rodowa. Mimo to ogląd zachowanych in situ zabytków pozwala już na wstępie stwierdzić, że w Rodowie mamy do czynienia $\mathrm{z}$ unikalnym w całych Prusach Książęcych zespołem dekoracji emblematycznych umieszczonych na ławach kościelnych oraz czterech obrazów sztalugowych ukazujących siłę modlitwy i wzorową hierarchię społeczną. Jeden z obrazów może być interpretowany jako próba wizualizacji związków bądź też zależności łączących duchowieństwo, chłopów i właścicieli dóbr ziemskich.

28 Anton Ulbrich, Kunstgeschichte Ostpreussens von der Ordenszeit bis zu Gegenwart (Frankfurt am Main: Verlag Veidlich 1932), 186; Katarzyna Wardzyńska, „Johannes Soeffrens (1660-po 1721) rzeźbiarz niderlandzki w Elblągu. Wstęp do monografii“, Porta Aurea 13 (2014): 141-156.

29 Gerhard Templin, „Handwerk im Wandel der Zeiten in Deutsch-Eylau“, Westpreußen Jahrbuch 45 (1995): 69.

30 Dalszych badań wymaga ustalenie, czy Selcke, który zbudował ołtarz w Iławie, wykonał także ołtarz w Rodowie. Na tym etapie analiz struktura ołtarza w Rodowie, jego kolumny o kręconych trzonach oraz suchy ornament wskazują na autorstwo Selckego.

31 Zasadniczej zmiany bryły kościoła, która nie wpłynęła na dyspozycję wnętrza, dokonano w 1859 r. dobudowując do nawy od strony zachodniej niewielką wieżę. Być może pierwotnie przy budynku stała drewniana dzwonnica. 
O ile dekoracje emblematyczne, oczywiście innej treści były wykonywane w kościołach luterańskich Prus Książęcych, to figuralne, nieemblematyczne malowidła pokazujące siłę modlitwy i wiary, w połączeniu z wersetami biblijnymi, są na tym terenie prawdziwym wyjątkiem ${ }^{32}$.

Jednym z zadań dekoracji emblematycznych w Rodowie było zapewne wskazanie na wysoką, dominującą pozycję społeczną kolatorów kościoła w Prusach Książęcych. Kolejnym - ukazanie praktycznej pobożności czerpiącej siły z modlitwy, stanowiącej wzór duchowego życia i funkcjonowania w lokalnej społeczności. Kwestią otwartą pozostanie oczywiście sposób absorbcji znaczeń poszczególnych przedstawień przez niewykształconych parafian. Ponieważ emblemy zostały zmodyfikowane w stosunku do oryginałów przez usunięcie epigramu (z pozostawieniem tylko lemmy i imago), powstają pytania, czy ich treść była dla każdego zrozumiała, czy też w pełni czytelna tylko dla fundatorów i dla duchownych mających dostęp do epigramu? Czy parafianie widzieli w nich ilustracje kazań głoszonych przez pastorów? Jakie były motywy tej fundacji, dokonanej przecież w niewielkim, leżącym na uboczu wiejskim kościółku, peryferyjnym wobec stołecznego Królewca, a nawet do biskupich Prabut i kościoła w Suszu, który rodzina von Schack ozdobiła na emporach bogatym zespołem scen biblijnych oraz okazałą lożą patronacką?

Trudno też określić precyzyjniej przyczynę, dla której Schackowie jako kompozycyjne pierwowzory programu dekoracji ław w Rodowie wybrali projekty przygotowane dla królewskiej wytwórni tapiserii we Francji. Być może uczynili to pod wpływem kultury dworu Ludwika XIV, której, podobnie jak część szlachty Prus Książęcych, rodzina ta ulegała. Jak wyżej wspomniano, Wilhelm Albrecht von Schack walczył w wojnach na terenie Francji, gdzie miał bezpośredni kontakt z kulturą dworską. Można też postawić tezę, że malowidła na ławach powstały z inicjatywy właścicieli wsi, którzy dostarczyli stosowne wzorce graficzne, a za ikonografię malowideł ściennych odpowiadał pastor związany być może z ruchem pietystycznym w Prusach Książęcych. Pastorem w Rodowie od września 1748 roku, również w czasie budowy nowego kościoła, był Andreas Pasternack. Przed nim w drugiej połowie XVII i na początku XVIII wieku posługę duchową pełnili pastorzy Johann Escher,

32 Wiele dekoracji malarskich wykorzystujących emblemy zostało zniszczonych lub rozproszonych, o czym świadczy m.in. odnaleziona przez Joannę Arszyńską płycina z kościoła w Górowie Iławeckim. 
Matthias Gutcke, Emanuel Görtz i Johannes Mäding. Któryś z nich mógł być autorem przekazu ikonograficznego rodowskich malowideł sztalugowych ${ }^{33}$.

\section{Pierwowzory dekoracji emblematycznej ław kościoła w Rodowie}

Kompozycje emblematycznej dekoracji malarskiej w kościele w Rodowie oparte zostały na ilustracjach pochodzących z dzieła Tapisseries du roy, ou sont representez les quatre elemens et les quatre saisons: avec les devises qvi les accompagnent \& leur explication = Königliche französische Tapezereyen, oder überauss schöne Sinn-Bilder, in welchen die vier Element, samt den vier Jahr-Zeiten, neben den Dencksprüchen und ihren Ausslegungen, vorgestellet. Księga ta, wydana pierwotnie przez André Félibiena w 1670 roku, zawierała grafiki będące pierwowzorami słynnej serii tapiserii zaprojektowanych i wykonanych dla dworu Ludwika XIV. Pierwsze niemieckojęzyczne edycje tego dzieła ukazały się u Jacoba Koppmayera w Augsburgu w 1687 i w 1690 roku, zdobione grafikami rytowanymi na podstawie francuskich wzorów przez Johanna Ulricha Kraussa ${ }^{34}$.

Niemieckie ilustracje powstały na podstawie dwóch serii rycin Sébastiena Le Clerc przygotowanych dla projektów tapiserii Charles’a Le Brun. Znajdujące się wśród nich emblemy „Quatre elemens” w niemieckiej edycji sygnowała Johanna Sybilla Krauss, wzorując się przy ich tworzeniu także na emblemach zaczerpniętych z księgi Jacques’a Bailly. Każdy z nich w wersji niemieckiej został wzbogacony o francusko- i niemieckojęzyczne objaśnienia (epigramy) według wersetów autorstwa m.in. Charles’a Perraulta i Jeana Chapelina. Dzieło Krauss uzupełniły emblemy, frontyspisy i dwa zdobione inicjały pochodzące ze wspomnianych „Quatre elemens” oraz dodatkowo z „Quatre saisons” - innego dzieła Le Clerca, z którego zaczerpnięto kolejne elementy zdobnicze dla wersji niemieckiej: gotyckie inicjały i winiety sygnowane przez Johanna Ulricha Kraussa ${ }^{35}$.

Wśród znajdujących się w polach płycin ławek w kościele w Rodowie zidentyfikowano głównie emblemy pochodzące z „Quatre elemens”. Treść ich

33 Daniel Heinrich Arnolds, Nachrichten von allen seit der Reformation an den Lutherischen Kirchen gestanden Predigern (Königsberg: Gottlieb Lebrecht Hartung, 1777), 418-419.

34 Pascal Francois Bertrand, "Tapestry Production at the Gobelins During the Reign of Louis XIV, 1661-1715", w Tapestries on the Baroque. The Threat of Splendour, red. Thomas P. Campbell (New Haven: Yale University Press 2007), 341-356.

35 Publikacja dostępna na stronie https://archive.org/details/tapisseriesduroy00feli (dostęp z 6.05.2019). 
przekazu wskazuje już we francuskim oryginale na cechy idealnego władcy. W Rodowie podkreślają one oczywiście przymioty właścicieli wsi i kolatorów kościoła von Schacków. Emblem żywiołu „Ognia” z kadzielnicą z płonącym ogniem - odwołuje się do płonącego przed Bogiem świętego ognia spalającego „miłe Panu” wonności. Ogień ten reprezentuje zbawienie i „Świętość Pana” („Gottseligkeit”), który jest „ogniem trawiącym” („Das Heilig Feuhr verzehr” - „Et Sacro capitur igni”). Z tym emblemem powiązany jest emblem drugi - „Dobroć”, czyli „Gütigkeit z objaśnieniem: „Moje światło oświeca drogę aby można było bezpiecznie płynąć” i dewizą: „In Publica Commoda Fulget”, wskazujący, że to Bóg posyła łaskawie światło latarni morskiej, aby wśród trudności życia prowadziło człowieka do bezpiecznej przystani.

„Powietrze” obrazuje emblemat z pszczołami wylatującymi z ula, ze wskazaniem w objaśnieniu na łagodność i łaskę jako cechy charakteryzujące idealnego króla: „Selindigkeit und Gnad des Koenig Zeichen hat”. Władcę - jak mówi objaśnienie - znają jego poddani, a ponieważ jest królem pszczół (jak pszczela królowa matka), jest też pełen łaski i dobroci. Z Do „Wody” odnosi się emblemat z dewizą i objaśnieniem Charles’a Perraulta: „Facit omnia laeta”. oraz przedstawieniem nurtu wody i żab, które w Rodowie zamieniły się w syreny. Zgodnie z objaśnieniem tego emblemu, umieszczonym poniżej imago, majestat króla przyniesie szczęście i bogactwo wszystkim, którzy są mu posłuszni.

„Ziemię” reprezentują w kościele w Rodowie dwa emblemy. Pierwszy z wyobrażeniem kwitnącego kwiatu słonecznika, podpisano dewizą: „Wie sich der Himmel regt, so werd ich auch bewegt" - objaśniając czytelnika, że władza króla wpływa bezpośrednio na poddanych, którzy muszą za nim podążać, tak jak słonecznik swym kwiatem podąża za słońcem. Drugi emblem: „Et regit, et servat”, opisany: „Er leitet hin und her, und ist der Schäflein wehr”, objaśniony przez Charles'a Perraulta informuje, że laska pasterska służy władcy do prowadzenia stada, a w razie potrzeby także do jego obrony przed wilkami. Król zatem nie tylko rządzi swym ludem, ale również broni go przed zewnętrznym wrogiem.

Wykorzystanie do dekoracji ław w Rodowie emblemów zaczerpniętych z francusko/niemieckiego dzieła jest - jak już wyżej wspomniano - w Prusach Książęcych wyjątkową inicjatywą i jak dotąd nie znaleziono podobnego zespołu tym obszarze ${ }^{36}$. W wielu ewangelickich kościołach Prus jako symbole

36 Ewentualna identyfikacja takich zabytków może być wynikiem wyłącznie poszukiwań archiwalnych i ikonograficznych, gdyż w kościołach poewangelickich na terenie dzisiejszych Mazur nie zachowała się dekoracja tego typu. 
ich wysokiej pozycji społecznej szlachty występują herby i spolia, które można stosunkowo łatwo zidentyfikować. Oczywiście rodzina von Schack także posługiwała się heraldyką jako narzędziem eksponowania rangi rodu, o czym świadczą choćby dekoracje empor, loży patronackiej i konfesjonału w jej drugim patronackim kościele - w Suszu. Odpowiedź na pytanie, dlaczego zdecydowała się na tak nietypowy, znacznie ambitniejszy emblematyczny program dekoracyjny w małym wiejskim kościółku pozostaje otwarte ${ }^{37}$.

\section{Malowidła sztalugowe}

Emblemy dekorujące ławki w kościele w Rodowie tworzą, według autora niniejszego artykułu, zespół obrazów podkreślających wiodącą rolę właściciela w życiu wiejskiej społeczności. Natomiast owalne malowidła nieznanego artysty, wiszące obecnie na ścianach świątyni, wprowadzają do jej przestrzeni, eksponując w czwartym malowidle ich pozycję, duchowieństwo i chłopów z parafii. Malowidła sztalugowe stanowią bowiem drugi bardzo ważny element wystroju rodowskiego kościoła. Trzy z nich objaśniają [naświetlają] znaczenie modlitwy jako jednego z najważniejszych elementów duchowego życia i płaszczyzny spotkania z Bogiem, czwarte zaś gloryfikuje, jak się wydaje, zalety stabilnego „luterańskiego” porządku społecznego opartego na przywódczej roli szlachty, służbie duchowieństwa i pracy chłopstwa.

Pierwszy (z czterech) obraz pokazuje króla Dawida podczas modlitwy przed Arką Przymierza i przytacza cytaty z Księgi Królewskiej (rozdz. 7, w. 27). Modlitwa króla jest zapowiedzią modlitw Nowego Testamentu, które dzięki Jezusowi trafiają bezpośrednio do Boga: „quia tu, Domine exercituum Deus Israël, revelasti aurem servi tui, dicens: Domum ædificabo tibi: propterea invenit servus tuus cor suum ut oraret te oratione hac". Co ważne, to modlitwa zaczerpnięta z Ewangelii według św. Jana: „Petite, et accipietis, ut gaudium vestrum sit plenum”) (rozdz. 16, w. 24-27) sprawia, że modlący się bezpośrednio z rogu bożej obfitości otrzymują łaski potrzebne do życia, a wypuszczanie strzał z łuku w stronę jaśniejących chmur wydaje się zachętą do wytrwałego zabiegania o opiekę Boga. Ponieważ zacytowany przy tej scenie werset „Eccesiasticus Oratio humiliantis se nubes penetrabit” pochodzi z niekanonicznej księgi Mądrości Syracha, nie ujawniono, w przeciwieństwie do pozostałych cytatów, jego rzeczywistego źródła. Siła tej modlitwy jak strzała

37 Birecki, „Architektura i sztuka”, 120. 
przenikającej do niebios, może być równie potężna jak modłów płynących z ust obficie błogosławionego przez Jahwe króla Dawida.

Drugi obraz kieruje uwagę obserwatora w stronę życia duchowego, przywołując starotestamentowe modlitwy i łaski otrzymywane przez proroka Daniela. Starotestamentowym źródłem błogosławieństwa było przestrzeganie Prawa, w Nowym Testamencie jest nim otrzymana łaska. Mówią o tym wersety przypisane klęczącemu na niewielkim wzgórzu Danielowi, pochodzące z Księgi Daniela (rozdz. 9, w. 9): „Tibi autem Domino Deo nostro misericordia et propitiatio, quia recessimus” oraz: „Septuaginta hebdomades abbreviatae sunt super populum tuum et super urbem sanctam tuam, ut consummetur paevaricatio, et finem accipiat peccatum, et deleatur iniquitas, et adducatur justitia sempiterna, et impleatur visio et prophetia, et ungatur Sanctus sanctorum" (w. 24). Centralnym punktem tego malowidła jest otwarte w stronę widza prezbiterium i ołtarz, do którego od lewej podchodzi Chrystus z kielichem w ręku, zachęcając stojącą naprzeciw niego Oblubienicę (Anima Christiana?) do wspólnej Wieczerzy słowami z Pieśni nad Pieśniami: „Comedite amici bibite et inebri animi charissimi” (rozdz. 5, w. 1). Oblubienica ta zdetronizowała w swym sercu panowanie skrępowanego króla (ukazanego po prawej), symbolizującego być może cielesność, naturę „starego człowieka” opisanego w Liście do Rzymian przez św. Pawła.

Malowidło trzecie wskazuje na moc modlitw wierzących/świętych (Orationes sanctorum), które, , chwaląc Boga, kierują się prosto do nieba. Modlitwę o niebiańskiej mocy czyta z trzymanej w ręku księgi klęczący pastor wraz z małżonką, zwracając się do Pana Szabatu: „Sanctus, Sanctus, Sanctus, Dominus, Deus Sabaoth”. Nieskuteczną modlitwę wypowiadają klęczący naprzeciw po prawej świeccy małżonkowie, których słowa jak cienkie nici zmierzają w stronę spraw przyziemnych: księgi wydatków i przychodów oraz przedmiotów codziennego użytku, takich jak umilające spędzanie czasu karty lub instrumenty muzyczne. Do gorliwej modlitwy zachęcają umieszczone na obrazie cytaty z Ewangelii według św. Jana (rozdz. 4, w. 23-24) - mówiące o służbie Bogu w duchu i prawdzie, oraz z Listu Jakuba (rozdz. 4, w. 3), o przyczynie nieotrzymania łaski od Boga, którą jest zły sposób kierowania próśb.

Czwarte i ostatnie malowidło, wiszące na północnej ścianie kościoła, pokazuje przede wszystkim trzy filary tworzące stabilny porządek społeczny, które stanowią trzy warstwy: szlachta, duchowieństwo i chłopstwo; obecność mieszczaństwa w Prusach Książęcych została pominięta. Autor tego przekazu przypomniał Salomonowy potrójny sznur: „et si quispiam praevaluerit contra 
unum duo resistent ei funiculus triplex difficile rumpitur” z Księgi Kaznodziei (rozdz. 4, w. 12). Sznur ten splata mężczyzna posługując się kołowrotem, na który ego bęben nawijają się i łączą trzy cieńsze sznury ciągnione od rycerza broniącego murów, kaznodziei odprawiającego nabożeństwo i chłopa pracującego w polu. W tekście biblijnym tak spleciony potrójny sznur symbolizuje silny związek mężczyzny i kobiety złączonych mocą Boga, natomiast w Rodowie oznacza siłę związku tych, którzy bronią („Defendo”), z tymi, co karmią („Nutrio”) i co się modlą („Doceo”). Zgodnie z tym przekazem szlachta, duchowieństwo i chłopi stanowić mają trwałą lokalną i ponadlokalną społeczność, tworząc - jak wskazuje przywołany cytat z Ewangelii św. Mateusza (rozdz. 16, w. 18) - skałę, na której budowany jest wspólnie Kościół Chrystusa ${ }^{38}$.

Rodowskie malowidła ufundowali zamożni i dobrze wykształceni patroni parafii, dbający - jak można przypuszczać - o życie duchowe swoich włościan-parafian. Ich intencja przejawiła się nie tylko w pokazaniu im za pomocą obrazów podstawowych prawd wiary, w tym zwłaszcza zbawczej roli Chrystusa, ale także uświadomieniu mocy i skuteczności modlitwy. Obrazy sztalugowe z tego kościoła mają bowiem duży potencjał kaznodziejski, umożliwiając wizualne zaprezentowanie wielu wątków biblijnych i społecznych. Położono w nich nacisk na moc modlitwy, na otrzymaną łaskę, na spotkanie się Kościoła z Oblubieńcem oraz - co pokazuje malowidło czwarte - na zalety stabilnego porządku społecznego, które wskazał Marcin Luter w kazaniu wygłoszonym podczas poświęcenia kaplicy zamku w Torgau w 1544 roku $^{39}$. Warto dodać, że [?] w XVI i XVII wieku wprowadzono wiele tzw. Kirchenstuhlordnungen, czyli ordynacji regulujących rozmieszczenie i zasady korzystania z siedzisk w kościołach, oddzielnie wytyczając miejsca dla parafian i władz zwierzchnich. Ordynacje te stanowiły element manifestacji wiodącej pozycji świeckich właścicieli wsi, którzy byli także duchowymi liderami wspólnoty, nad którą opiekę religijną sprawowali zatrudniani przez nich luterańscy ministrowie. Program malarski w Rodowie jest wyjątkowym w Prusach Książęcych dowodem luterańskiej tradycji użytkowania przestrzeni kościoła ${ }^{40}$.

38 Zatarta scena uczty w prawym dolnym rogu mogłaby wzbogacić interpretację czwartego malowidła.

39 Hans Chr. Sens, Evangelische Schlosskirche Torgau (Regensburg: Schnell\&Steiner Verlag, 2007), 3.

40 Olivier Meys, Memoria und Bekenntnis. Die Grabdenkmäler evangelischer Landesherren im Heiligen Römischen Reich Deutscher Nation im Zeitalter der Konfessionalisierung (Regensburg: Schnell \& Steiner Verlag, 2009), 50-56. 


\section{Podsumowanie}

Emblemy były w XVII wieku jednym z ważniejszych elementów dekoracyjnych w kościołach basenu Morza Bałtyckiego, od Danii przez Szwecję po Tallin, przez Szlezwik-Holsztyn, Turyngię, Saksonię, po Śląsk ${ }^{41}$. Powszechniejsze występowanie emblemów w programach dekoracyjnych kościołów luterańskich przyciągnęło już uwagę kilku badaczy. Mara R. Wade, podążając za studiami Katarzyny Cieślak na temat emblematyki w Prusach Królewskich, analizowała m.in. dekoracje tego typu w luterańskich kościołach Gdańska. Obydwie badaczki sygnalizowały znaczenie programów emblematycznych tworzonych między 1639 a 1694 rokiem w tamtejszych kościołach miast pruskich. W późniejszym okresie - w pierwszych dwóch dekadach XVIII wieku - dekoracje emblematyczne wykonywano już raczej sporadycznie ${ }^{42}$. Zagadnienia te niewątpliwie wymagają dalszych badań i interpretacji.

Emblemy z Rodowa należą do najpóźniejszych przykładów stosowania tego typu dekoracji w obu częściach Prus ${ }^{43}$. Powstały zapewne pod koniec XVII wieku, wykonane razem z częścią nowego wyposażenia (ambona Soeffrensa jest datowana na 1690 rok), ale były przeznaczone jeszcze do starszego kościoła, sprzed 1754 roku. Podobnie można datować cztery malowidła osadzone w nowym kościele na ścianach lateralnych. Wstępna analiza ich treści wskazuje na oddziaływanie pobożności pietystycznej płynącej z Królewca w stronę parafii pruskoksiążęcych, a także nowych źródeł inspiracji artystycznych, gdyż Prusy Książęce na przełomie XVII i XVIII wieku znalazły się pod

${ }^{41}$ Szerzej zob. Emblematik im Ostseeraum - Emblematics Around the Baltic, red. Ingrid Höpel, Lars O. Larsson (Kiel: Ludwig Verlag 2016); Marcin Wisłocki, "From Emblem Books to Ecclesiastical Space; Emblems and Quasi-Emblems in Protestant Churches on the Southern Coast of Baltic Sea and their Devotional Background", w The Emblem in Scandinavia and the Baltic, red. Simon McKeown, Mara R. Wade, Glasgow Emblem Studies 11 (2005): 263-294. Wisłocki, Marcin. 2005, "Der Einfluss Johannes Arndts und der verinnerlichten Frömmigkeitsrichtung des 17. Jahrhunderts auf die kirchliche Kunst im südlichen Ostseeraum." In Interdisziplinäre Pietismusforschungen. Beiträge zum ersten Internationalen Kongress für Pietismusforschung 2001, edited by U. Sträter, H. Lehmann, Th. Müller-Bahlke, J. Wallmann, Tübingen: Verlag der Franckeschen Stiftungen im Max Niemeyer Verlag, 375-389.

42 Mara R. Wade, “Sebald Meinhard's Liturgical Emblems in Danzig”, w The Emblem in Scandinavia and the Baltic, red. Simon McKeown, Mara R. Wade, Glasgow Emblem Studies 11 (2006): 205-230; Katarzyna Cieślak, "Emblematic Programmes in Seventeenth-Century Gdańsk Churches in the Light of Contemporary Protestantism: an Essay and Documentation”, Emblematica: An Interdisciplinary Journal for Emblem Studies 9 (1995): 21-44.

43 Katarzyna Cieślak, „Emblematyka w XVII-wiecznych wnętrzach kościelnych Gdańska”, w Sztuka XVII wieku w Polsce, red. Teresa Hrankowska (Warszawa: Arx Regia Press, 1994), 205-219. Autor podejmie się w przyszłości dokładniejszego datowania wyposażenia. 
wpływem sztuki francuskiej. Jak się okazuje, wpływy te dotyczyły nie tylko architektury pałacowej (Drogosze Jeana de Collas, Friedrichstein i Kamieniec Suski według projektów Jeana de Bodt) oraz kościelnej (kościół kalwiński w Kamieńcu Suskim projektu de Bodta), ale również malarstwa ${ }^{44}$.

\section{Bibliografia}

Arnolds Daniel Heinrich. 1777, Nachrichten von allen seit der Reformation an den Lutherischen Kirchen gestanden Predigern, Königsberg: Gottlieb Lebrecht Hartung,

Bertrand, Pascal-Francois. 2007, "Tapestry production at the Gobelins during the reign of Louis XIV, 1661-1715." In Tapestries on the Baroque. The threat of splendour, edited by Thomas P. Campbell, 341-356. New Haven: Yale University Press.

Birecki, Piotr, "Reformed Church Buildings in the Grand Duchy of Lithuania in the Modern Period", Reformation and Renaissance Review 17, nr 1 (April), red. Piotr Wilczek, Simon Burton, (2015): 17-30.

Birecki, Piotr, „The Lutheran Church as a Space of Representation of Social Standing in Early Modern Ducal Prussia" (referat na sesji Indifferent Things? The Material and Ceremonial Church Practices in the 16th and 17th Centuries in the Baltic Sea Region. The conference in the series of „Homburger Gespräche“ and the 5th conference in honour of Prof. Sten Karling (1906-1987), [Tallin 14.09.-16.09.2017] - artykuł w druku.

Birecki, Piotr. 2017, "Architektura i sztuka na terenie Prus Książęcych (1525-1657)". In W 500-lecie Reformacji (1517-2017). Z dziejów Kościołów ewangelickich $w$ dawnych Prusach Królewskich i Książęcych, II, tereny dawnych Prus Ksiązęcych, edited by J. Kłaczkow, G. Jasiński, P. Birecki, 80-138. Toruń: Adam Marszałek Press.

Chrzanowski, Tadeusz. 1994, „Kościół w Starym mieście pod Dzierzgoniem pw. św. Apostołów Piotra i Pawła - emblematyka w służbie protestantyzmu". In Sztuka Prus XIII-XVIII wieku, edited by Michał Woźniak, 199-226. Toruń: University Press.

Cieślak, Katarzyna. 1988, ”Pierwowzory graficzne epitafiów obrazowych w Gdańsku a problemy ich ikonografii." Biuletyn Historii Sztuki, 3: 201-224.

Cieślak, Katarzyna. 1994, ”Emblematyka w XVII-wiecznych wnętrzach kościelnych Gdańska." In Sztuka XVII wieku w Polsce, edited by Teresa Hrankowska, 205-219. Warszawa: Arx Regia Press.

44 Richard Gawthrop, Pietism and the making of eighteenth century Prussia (Cambridge: University Press 1993), 200-269; Dagmara Wójcik, „Ze studiów nad programem ideowym kościoła w Starym Mieście pod Dzierzgoniem”, w Sztuka i dialog wyznań, red. Jan Harasimowicz (Warszawa: Ejko Press 2000), 325-336; Carl von Lorck, Landschlösser und Gutshäuser in Ost- und Westpreussen (Frankfurt am Main: Veidlich Verlag, 1965), 106-107; Herman von Dohna, „Finckenstein - Kamieniec“, w Ostpreußische Gutshäuser in Polen, red. Kamila Wróblewska (München: C. H. Beck Verlag, 1995), 93. 
Cieślak, Katarzyna. 1995, “Emblematic Programmes in Seventeenth-Century Gdańsk Churches in the Light of Contemporary Protestantism: an Essay and Documentation.” In Emblematica: An Interdisciplinary Journal for Emblem Studies, 9, 1: 21-44.

Dohna, Hermann Graf zu. 1995, "Finckenstein - Kamieniec. "In Ostpreußische Gutshäuser in Polen, edited by Kamila Wróblewska, , 93. München: C. H. Beck Verlag.

Gawthrop, Richard. 1993, Pietism and the making of eighteenth century Prussia. Cambridge: University Press.

Harasimowicz, Jan. 1996, Kunst als Glaubensbekenntnis. Baden-Baden: Valentin Koerner Verlag.

Harasimowicz, Jan. 2017, Sichtbares Wort. Die Kunst als Medium der Konfessionalisierung und Intensivierung des Glaubens in der Frühen Neuzeit. Regensburg: Schnell \& Steiner.

Harasimowicz, Jan. 2017, “Die Brautmystik in der mitteleuropäischen Kunst der Frühen Neuzeit.“ In Die Kunst als Medium der Konfessionalisierung und Intensivierung des Glaubens in der Frühen Neuzeit, edited by Jan Harasimowicz and others, 227-241. Regensburg: Schnell \& Steiner.

Harasimowicz, Jan. 2017, “Der Einfluss des Pietismus auf Architektur und bildende Künste. Sichtbares Wort.“ In Die Kunst als Medium der Konfessionalisierung und Intensivierung des Glaubens in der Frühen Neuzeit, edited by Jan Harasimowicz and others, 259-272. Regensburg: Schnell \& Steiner.

Ingrid Höpel, Lars Olof Larsson (ed.). 2016, Emblematik im Ostseeraum - Emblematics around the Baltic. Kiel: Verlag Ludwig.

Kaufmann, Karl, Josef. 1937, Geschichte der Stadt Rosenberg in Westpreussen. Rosenberg: City Press.

Klemp, Aleksander. 1994, Protestanci $w$ dobrach prywatnych $w$ Prusach Królewskich od drugiej połowy XVII do drugiej połowy XVIII wieku. Gdańsk: Ossolineum Press.

Kozina, Irma, Jan K. Ostrowski. 1992, “ Grabfahnen mit Porträtdarstellungen in Polen und in Ostpreußen “. Zeitschrift für Kunstgeschichte 55, Nr. 2, 225-255.

Lorck, Carl von. 1965, Landschlösser und Gutshäuser in Ost- und Westpreussen. Frankfurt am Main: Veidlich Verlag.

Małłek, Janusz. 2012, ”Początki protestantyzmu w Prusach Książęcych”. In Opera Selec$t a$, vol. IV, edited by Maria Dąbrowska, 233-247, Toruń: University Press.

Meys, Oliver. 2009, Memoria und Bekenntnis. Die Grabdenkmäler evangelischer Landesherren im Heiligen Römischen Reich Deutscher Nation im Zeitalter der Konfessionalisierung. Regensburg: Schnell \& Steiner.

Perlbach, Max. 1902, “Zur Geschichte des ältesten Großgrundbesitzes im Deutschordenslande Preussen: Dietrich von Dypenow und Dietrich Stange.“, Altpreussische Monatsschrift 39 : 78-124.

Schmid, Bernhard. 1906, “Gr. Rodau“. In Die Bau- und Kunstdenkmäler der Provinz Westpreussen: Der Kreis Rosenberg, 198-201. Danzig: Kommissions Verlag. 
Sens, Hans Christian, Evangelische Schlosskirche Torgau Regensburg: Schell\&Steiner Verlag, 2007.

Szczepański, Łukasz. "Życie i kariera wojskowa generała majora Wilhelma Albrechta Schack von Wittenau”, Suski Słownik Biograficzny, 56-58, accessed September 11, 2017, http://docplayer.pl/43206697-Zycie-i-kariera-wojskowa-generala-majora-wilhelma-albrechta-schack-von-wittenau.html.

Templin, Gerhard. „Handwerk im Wandel der Zeiten in Deutsch-Eylau“, Westpreußen Jahrbuch 45 (1995).

Ulbrich, Anton. 1932, Kunstgeschichte Ostpreussens. Frankfurt am Main: Verlag Weidlich, 1932.

Wardzyńska, Katarzyna. 2014, Johannes Soeffrens (1660-po 1721) rzeźbiarz niderlandzki w Elblagu. Wstęp do monografii, in: Porta Aurea 13. Gdańsk: University Press.

Wade, Mara R. 2006, "Sebald Meinhard's Liturgical Emblems in Danzig.” In The Emblem in Scandinavia and the Baltic, edited by Simon McKeown, Mara R. Wade, Glasgow Emblem Studies, 205-230. Glasgow: Glasgow University Press.

Wisłocki, Marcin. 2005, “Der Einfluss Johannes Arndts und der verinnerlichten Frömmigkeitsrichtung des 17. Jahrhunderts auf die kirchliche Kunst im südlichen Ostseeraum." In Interdisziplinäre Pietismusforschungen. Beiträge zum ersten Internationalen Kongress für Pietismusforschung 2001, edited by U. Sträter, H. Lehmann, Th. Müller-Bahlke, J. Wallmann, Tübingen: Verlag der Franckeschen Stiftungen im Max Niemeyer Verlag, 375-389.

Wisłocki, Marcin. 2006, "From Emblem Books to Ecclesiastical Space; Emblems and Quasi-Emblems in Protestant Churches on the Southern Coast of Baltic Sea and their Devotional Background.” In The Emblem in Scandinavia and the Baltic, edited by Simon McKeown, Mara R. Wade, Glasgow Emblem Studies Glasgow, 263-294. Glasgow: University Press.

Wójcik, Dagmara. 2000, “Ze studiów nad programem ideowym kościoła w Starym Mieście pod Dzierzgoniem.” In Sztuka i dialog wyznań, edited by Jan Harasimowicz, 325-336. Warszawa: EJKO Press. 